Article

\title{
Intra-Camp Coalitions in Direct Democracy: Evidence from Referendums on Asylum
}

\author{
Laurent Bernhard \\ Swiss Centre of Expertise in the Social Sciences (FORS), University of Lausanne, 1015 Lausanne, Switzerland; \\ E-Mail: laurent.bernhard@fors.unil.ch
}

Submitted: 14 December 2018 | Accepted: 12 March 2019 | Published: 27 June 2019

\begin{abstract}
This article seeks to advance the underdeveloped literature on coalitions in direct democracy by considering intra-camp coalitions (ICC) at the level of political elites. The binary format of ballot measures leads to the formation of two opposing camps (i.e., supporters and opponents). However, political actors who belong to a given camp are not obliged to work with each other in the course of direct-democratic campaigns. I argue that the formation of ICC is ideologically driven, as political actors may be inclined to more closely cooperate with those actors who share their beliefs. Therefore, I expect that the actors of a given camp will create ideologically more homogeneous coalitions. The empirical analysis focuses on the salient issue of asylum by examining the cooperative ties between political organizations that participated in two Swiss referendum campaigns. Drawing on the CONCOR algorithm, I identify the actor compositions of the four camps in question. I show that the organizations that form the two main ICC on either side significantly differ from each other in terms of their positioning on the left-right scale. Hence, actors who campaign on the same side tend to separate into coalitions that are ideologically more homogeneous.
\end{abstract}

\section{Keywords}

asylum; coalitions; direct democracy; referendum; Switzerland

\section{Issue}

This article is part of the issue, "The Politics, Promise and Peril of Direct Democracy", edited by Todd Donovan (Western Washington University, USA).

(C) 2019 by the author; licensee Cogitatio (Lisbon, Portugal). This article is licensed under a Creative Commons Attribution 4.0 International License (CC BY).

\section{Introduction}

In contrast to electoral studies, the scholarly literature on direct democracy thus far neglects the analysis of coalitions. This article proposes focusing on the actor composition of both supporters and opponents in intra-camp coalitions (ICC) at the level of political elites by examining ballot measures in the context of referendum campaigns. Direct-democratic votes are usually characterized by two options, given that issue-specific propositions can either be accepted or rejected. This binary format leads to the formation of two opposing camps: supporters who advocate for a reform and opponents who want to maintain the status quo. However, political actors who belong to a given camp are not obliged to work with each other during their engagement in a campaign. This article is interested in what shapes the composition of supporters' and opponents' camps in referendum campaigns. I argue that the formation of ICC is ideologically driven and that shared beliefs are expected to facilitate cooperation between actors. In contrast, actors with unshared beliefs are unlikely to join forces, as cooperation would likely give rise to disagreements and conflicts. I therefore expect the actors of a given camp to separate into coalitions that are ideologically more homogeneous.

This empirical analysis focuses on the salient issue of asylum by considering ICC in the context of two referendums that took place in Switzerland at the federal level in 2006 and 2016. These cases differ in terms of actor constellation. While the 2006 referendum essentially gave rise to a divide between the left and the right, the 2016 referendum pitted moderate against extreme actors. The data used in this study are based on cooperative ties that were reported in the framework of ex- 
post interviews with representatives of the political organizations (state actors, parties, economic associations, citizen groups, and committees) that actively took part in the two selected referendum campaigns. The empirical investigation relies on network analysis by making use of the CONCOR algorithm in order to identify the compositions of the two main coalitions for each of the four camps under scrutiny (i.e., the supporters and opponents of the two selected ballot measures). In line with my expectation, I show that coalition formation is ideologically driven. More specifically, I demonstrate that the organizations of the two main ICC on either side consistently differ from each other in a statistically significant way in regard to their positioning on the left-right scale. Hence, actors of a given camp tend to split into ideologically more homogeneous coalitions.

The remainder of this article is organized as follows. Section 2 develops the theoretical argument. Section 3 focuses on the research design, including a discussion of the case selection as well as a description of the data and the method of analysis. Section 4 is devoted to the results of the empirical analysis. Finally, Section 5 summarizes the main findings of this article and presents its main implications.

\section{Theoretical Argument}

As opposed to electoral studies (e.g., Müller \& Strøm, 2000), the analysis of coalitions has not figured prominently in research on direct democracy so far. To my knowledge, the contributions by Bowler and Hanneman (2006), Kriesi $(2005,2006)$, and Manweller (2005) are the exception. This article aims to contribute to the literature by more closely examining the internal structure of the two opposing camps (i.e., supporters and opponents of ballot measures). In general, political actors face strong incentives to attract a maximum number of allies in referendum campaigns. The rationale behind this assumption relates to the fact that citizens have the final say. As the political elites do not control the outcome of the vote, the formation of large camps is an effective way of attempting to enhance their chances of succeeding at the polls. However, this comes at a price. Due to their actor heterogeneity, broad coalitions are not easy to manage. While the binary format of direct-democratic votes imposes the formation of two camps, the various organizations involved within a given camp may wish to adopt substantively distinct campaign strategies. In order to cope with this conflict potential, political actors are expected to form ICC. In the following, I will argue that their composition is decisively shaped by the beliefs of the participating actors.

Inter-organizational cooperation in direct democracy is best described as ad hoc issue coalitions (Mahoney, 2007). Such coalitions form according to an instrumental logic. Their members work together in pursuit of a common issue-specific goal, as they either advocate for or against the passage of ballot measures. In line with re- source mobilization theory (McCarthy \& Zald, 1977), political actors can be expected to join coalitions in order to pool different types of resources (such as money, staff, volunteers, know-how, and reputation) and wage effective campaigns. Since ad hoc issue coalitions emerge for the purpose of a single campaign, they typically dissolve once the vote takes place (Manweller, 2005). Therefore, each direct-democratic vote is a rather unique event that is hardly connected to other votes, even those that take place simultaneously.

When it comes to coalition formation, the problem of size occurs in different terms in direct democracy than in representative democracy. According to the literature on government formation, parties in representative democracies tend to form coalitions that are just big enough to obtain a parliamentary majority. In contrast to these 'minimal winning coalitions' (Riker, 1962), actors involved in referendums and initiatives seek to secure the support of as many organizations as possible. Given that the decision-making authority eludes the elites, the formation of broadly supported camps is a central means by which political actors seek to influence the outcome of direct-democratic votes. In line with this reasoning, Kriesi $(2005$, p. 65,2006$)$ showed that in the case of Switzerland, the chances of success at the polls increases the larger a given camp is. As coalition size is a key determinant of the outcome of direct-democratic votes, political elites may seek to gather as many actors as possible behind their own position.

Yet the complexity of coalition work gets challenged as the number of organizations increases. Large camps typically face the problem of heterogeneity, since actors are likely to stem from different backgrounds. The socalled 'extension dilemma' (Jasper, 2006, pp. 127-128) states that 'the further you reach out your alliance, the more diverse it will become and the less unified'. Camps with numerous actors are notoriously plagued by ideological conflicts. In particular, disunity between moderate and radical strands is prone to give rise to endless quarrels over the strategies to be adopted during referendum campaigns. Such broad coalitions typically face major difficulties when they are unable to bridge disparate beliefs.

To overcome the problems posed by heterogeneity, political actors are expected to form ICC with other actors who share their beliefs. In other words, even when political actors are on the same camp in a given referendum campaign, they may choose not to work closely together due to ideological barriers. In line with this reasoning, social movement scholars established that groups do not join forces unless they share at least some common beliefs (van Dyke \& McCammon, 2010). In a similar vein, Manweller (2005) found that activists who launched initiatives in U.S. states best resolved internal disagreements by fractionalizing into two ideologically purer groups.

Based on these considerations, organizations should split according to ideological criteria. I therefore expect 
ideologically distinct ICC to emerge on both supporters' and opponents' sides of direct-democratic campaigns.

\section{Research Design}

\subsection{Case Selection}

To test this expectation, I examine two referendums on asylum that took place in Switzerland in 2006 and 2016. As is the case of many OECD countries, this topic has ranked high on the political agenda over the last decades (Steiner, 2000). The well-developed institutions of direct democracy have provided political organizations with a powerful opportunity for politicizing asylum issues in the Swiss context (Bernhard, 2012, pp. 68-72). I selected the 2006 and 2016 referendums in order to analyze varying actor constellations. Whereas the left-right conflict is predominantly available in direct-democratic votes, the unbundling of issues can occasionally lead to cross-cutting cleavages (Bowler \& Hanneman, 2006). The ballot measure submitted in 2006 pitted actors from the radical right and the moderate right against challengers from the left, civil society, and some dissidents from the moderate right. This classic antagonism in the Swiss asylum domain was the result of a decisive tightening reform of the federal asylum law. Its main provisions were concerned with restricting access to asylum applications and reducing the attractiveness of Switzerland as a destination country. In contrast, the vote held in 2016 gave rise to a cleavage between moderate and radical forces. While the organizations from the mainstream came out in favor of the reform, both radical left and radical right were against it. This rather unusual alignment was due to the policy orientation of the reform. This ballot measure can be considered as a paradigmatic case of streamlining (Bernhard \& Kaufmann, 2018), as it aimed to speed up asylum procedures and to structurally reorganize competences and responsibilities within the Swiss asylum domain. Participating voters eventually delivered a decisive verdict on both reforms by accepting them by a twothirds majority.

\subsection{Data and Methods}

The data used for this empirical analysis were collected in the framework of ex-post interviews immediately following the respective votes. The rationale behind this data collection strategy is that information regarding cooperation is gathered most precisely from the actors involved. I surveyed the representatives of the organizations that actively took part in the two referendum campaigns. I selected the organizations on the basis of various sources: the parliamentary debates, the campaign for the collection of signatures, voting recommendations, and the press, as well as websites more generally. Due to this procedure, I am confident that I included the most important organizations. There were no refusals when I contacted the interview partners. The absence of missing in- formation is due to the fact that Swiss political actors are motivated to participate in such interviews. In total, there were 46 interviews in 2006 and 31 in 2016. The elite population in question includes five types of actors: state actors, parties, economic associations, citizen groups, and committees, i.e., umbrella organizations that form in an ad hoc manner for the purpose of specific referendum campaigns.

I relied on the cooperative ties between the organizations in question to identify the ICC. In the framework of the ex-post interviews, campaign managers were presented with the complete list of the selected organizations. They were then asked to mark the organizations on the list with which they had closely collaborated during the course of the campaign. After they had gone through the list, I asked them to indicate the three organizations with which they had collaborated particularly closely. Finally, I asked which one organization from among the three they had most closely collaborated with. I then recoded this information in a square $\mathrm{N} \times \mathrm{N}$ matrix in which rows and columns consist of the same political organizations. The number ' 1 ' indicates a collaborative relationship, ' 2 ' indicates a particularly close relationship, and ' 3 ' represents the closest collaborative tie. Isolated actors, i.e., organizations without any connections to others, were removed from this analysis. This was relevant to three supporters of the tightening reform - the Geneva Citizens' Movement, the Party of Liberties, and the Swiss Farmers' Union.

I draw on network analysis to examine the coalition structures on the basis of this type of relational data. More specifically, I use block modeling, which allows me to distinguish between structurally equivalent groups of actors based on their cooperative relationships. Structural equivalence is met when two or more actors jointly have similar ties with third actors independently of their ties with each other. A block model consists of two elements (Wasserman \& Faust, 1999, p. 395): 1) a partition of actors in the network into discrete subsets called positions, and 2) a statement of the presence or absence of a tie within or between the positions for each pair of positions. I use the CONCOR algorithm, which applies successive splits to the network. In the first step, the procedure divides the set of actors into two structurally equivalent groups. Next, each group is broken down into another two structurally equivalent sub-groups, and so forth. Due to the small number of observations, I decided to stop the procedure after the second step. Since the organizations involved in a given campaign do not usually cooperate with peers aligned with the rival camps at all, the first split is expected to generate supporters and opponents. If this is the case, the second split will reveal the composition of the two main ICC on either side.

As to the independent variable, my measure of ideology refers to the self-reported positioning on the leftright axis. As is common in survey questionnaires, I use a scale that ranges from 0 (completely left) to 10 (completely right). For the present analysis, I decided to drop 
the Swiss Red Cross from the analysis because its representative refused to answer the question on ideology.

\section{Empirical Analysis}

As expected, the first split applied by CONCOR divides the supporters from the opponents in both ballot measures. The second split produces two groups for each of the four camps under investigation. Table 1 provides an overview of these eight ICC.

The two main ICC of each camp vary considerably in terms of their ideological orientation. In the case of the opponents to the 2006 tightening reform, the mean score of the first coalition on the self-reported positioning of the left-right scale is 2.48 , while the second coalition comes close to the political center $(M=4.30)$. An independent samples t-test reveals that the organizations of the former are significantly more to the left than the latter $(t=-3.264, p=0.003)$. The left-leaning coalition has 21 organizations. As is visible in Table A.1 in the Appendix, among these organizations are the main parties from the left (Social Democrats and Greens), some trade unions, several citizen groups that defend the rights of migrants, as well as two committees. However, this coalition is not confined to organizations from the left. In addition to some centrist parties (Evangelical People's Party and two cantonal sections of the Christian Democrats), it counts a dissident organization from the moderate right in its ranks (Free Democrats of Geneva). I therefore label this coalition 'left and allies'. The coalition of 'moderates' is made up of committees and citizen groups $(n=10)$. The most powerful organization of this ICC is the so-called 'right-wing committee against the asylum law'. Ideologically close to the moderate right, it mobilized quite intensively against the tightening reform. In addition to the Swiss Aid for Refugees and Amnesty International, this coalition attracted several religious organizations (e.g., the Protestant and the Catholic Churches).

In the case of the supporters of the tightening reform, CONCOR separates the 'moderate right' from the 'radical right'. This designation is justified in light of the mean scores displayed by these two ICC ( $M=6.43$ vs. 8.25 ).
According to a t-test, the ideological positioning of the members of these two groups are significantly distinct at the $5 \%$ error level $(t=2.292, p=0.048)$. The exact composition of these two ICC is available in Table A.2. The organizations from the moderate right $(n=7)$ included powerful federal authorities (Federal Department of Justice and Police and Federal Office for Migration), three parties (Free Democrats, Christian Democrats, and Liberals), as well as two business groups (Small Business Association, and Swiss Employers' Federation). The radical right coalition was only composed of four organizations. The levels of power reveal that it was dominated by the Swiss People's Party, the country's largest party.

I now address the ICC in the case of the 2016 streamlining reform. As far as the opponents are concerned, two clearly distinctive coalitions emerge in ideological terms - the 'radical left' and the 'radical right'. The mean of the self-reported ideology on the left-right axis equals 1.00 for the radical left and 7.25 for the radical right. Unsurprisingly, the means of these two groups are significantly different from each other $(t=9.934, p=0.000)$. The list in Table A.3 shows that each ICC included four organizations. On the radical left, three out of the four organizations are based in the French-speaking part of Switzerland (the committee called 'Appeal for the protection of the right to asylum', the Trotskyites from Solidarity, and the citizen group Stop exclusion). On the radical right, the Swiss People's Party joined forces with another party (Swiss Democrats), an economic association (Homeowners Association Switzerland), and a conservative citizen group (Security for all!). A closer look at the cooperative ties in the opponents' camp reveals that there was no joint work at all between the members of these two coalitions. Despite the fact that both campaigned for the rejection of the streamlining reform, the organizations from the 'no camp' restricted their cooperation to actors with similar beliefs. This is due to the fact that these two radical groups opposed this ballot measure for entirely different reasons.

The findings prove to be somewhat less spectacular on the side of supporters. The two ICC significantly differ from each other when it comes to their ideological posi-

Table 1. Overview of ICC by ballot measure.

\begin{tabular}{|c|c|c|c|}
\hline & Camp Affiliation & Left-Right (0-10) & Number of Organizations \\
\hline \multicolumn{4}{|c|}{ Tightening Reform (2006) } \\
\hline 1 Left and allies & opponents & 2.48 & 21 \\
\hline 2 Moderates & opponents & 4.30 & 10 \\
\hline 3 Moderate right & supporters & 6.43 & 7 \\
\hline 4 Radical right & supporters & 8.25 & 4 \\
\hline \multicolumn{4}{|c|}{ Streamlining Reform (2016) } \\
\hline 1 Radical left & opponents & 1.00 & 4 \\
\hline 2 Radical right & opponents & 7.25 & 4 \\
\hline 3 Left and allies & supporters & 3.25 & 12 \\
\hline 4 Moderates & supporters & 5.00 & 11 \\
\hline
\end{tabular}


tioning ( $t=2.888, p=0.009)$. The twelve organizations comprising the 'left and allies' coalition exhibit an average score of 3.26 on the left-right scale, while the eleven members of the 'moderates' ICC have a score that is exactly in the middle $(M=5.00)$. Despite this basic pattern, there are some overlaps (see Table A.4). On the one hand, the CONCOR algorithm assigns three centrist organizations to the left-leaning coalition (Amnesty International, Operation Libero, and the Conference of Swiss Bishops). On the other hand, it is striking that the Social Democrats from the left are part of the 'moderates' group. A closer look reveals that this party had close ties with the Federal Department of Justice and Police. This cooperation can be explained by the fact that the minister in charge of this reform was a member of the Social Democrats at that time.

\section{Conclusion}

This article aimed to contribute to the underdeveloped literature on coalitions in direct democracy by examining the composition of ICC. The binary format of ballot measures leads to the formation of two opposing camps-supporters and opponents. However, political actors who advocate for or against the passage of issuespecific propositions are not obliged to cooperate closely with actors who defend the same position during a particular referendum campaign. While coalitions are advantageous for pooling the resources of their members, increasing the number of coalition partners introduces the problem of heterogeneity. Due to ideological differences among political actors, disagreements and conflicts over substantial campaign decisions are likely to occur. In order to avoid such impediments to cooperation, I expected that political actors on either camp would form coalitions that were ideologically more homogeneous, while being distinctive from each other.

The empirical analysis, which focuses on two referendums on asylum held in Switzerland at the federal level in 2006 and 2016 respectively, finds that the formation of ICC is ideologically driven. Based on network analysis tools, I demonstrated that the organizations that form the four camps under scrutiny significantly differ from one another when it comes to their average positioning on the left-right axis. Hence, diverging beliefs tend to discourage political actors from joining forces during campaigns. The opponents of the streamlining reform probably illustrate this finding best. In this case, the organizations from the radical left and the radical right did not cooperate with each other at all, despite their pursuit of the same goal of defeating the reform.

As to the limitations of this contribution, some caution must be exercised when generalizing the results presented here. Indeed, this empirical analysis focuses on a narrow selection of cases: the organizations that participated in two direct-democratic campaigns on asylum in the peculiar Swiss political system. I would therefore like to encourage scholars who work on coalitions to ex- pand the number of ballot measures, issue domains, and country contexts under examination. Additionally, I believe that more detailed analyses would help to provide an understanding of the dynamic processes of coalition formation in direct democracy by more carefully examining the mechanisms that produce, or fail to produce, coalitions between political actors. Due to the absence of this kind of research, the literature on social movements may provide guidance for such endeavors (van Dyke \& McCammon, 2010).

Future studies may further explore the conditions under which political actors that are engaged in directdemocratic campaigns form ideologically homogeneous ICC. Ceteris paribus, this is more likely to occur the more organizations decide to go public on a given camp. It can be assumed that higher numbers of actors increase the probability of diverging beliefs. In order to cope with this challenge, participating actors may factionalize according to ideological criteria. An illustrative example of such intra-camp divisions is the 2016 Italian constitutional referendum (Bull, 2016; Pasquino \& Valbruzzi, 2017), which led to the resignation of Prime Minster Matteo Renzi. In this case, the numerous opponents of this institutional reform regrouped themselves into several committees. The two most important ones were the 'Committee for No', which was formed based on the initiative of the main parties from the right, and 'I Vote No', which was created by civil society actors and attracted opponents from the left. Based on this organizational structure, it seems rather obvious that the members of these two committees did not work together closely. Similar patterns are likely to have emerged from the 2014 Scottish independence referendum (Paterson, 2015) and the 2016 Brexit referendum (Clarke, Goodwin, \& Whiteley, 2017), given that in both cases a plethora of actors with distinctive beliefs belonged to the same camp.

Another promising avenue for research involves considering the effects of coalition structures. Given that rational actors ultimately aim to win direct-democratic votes, scholars could analyze whether the formation of ideologically-driven ICC increases their chances of success at the polls. Since homogeneous coalitions are less prone to suffering from internal conflicts, political actors may be able to campaign in an effective manner. However, if members of heterogeneous coalitions manage to avoid major conflicts, they are likely to benefit from economies of scale due to the pooling of their resources. This pooling of resources would allow them to achieve a higher level of attention among citizens, thus increasing the likelihood of bringing their engagement to a victorious end.

\section{Acknowledgments}

The author would like to thank the editorial team at Politics and Governance as well as Todd Donovan and the two anonymous reviewers for their helpful comments. 


\section{Conflict of Interests}

The author declares no conflict of interests.

\section{References}

Bernhard, L. (2012). Campaign strategy in direct democracy. Basingstoke: Palgrave Macmillan.

Bernhard, L., \& Kaufmann, D. (2018). Coping with the asylum challenge: Tightening and streamlining policies in Western Europe. Journal of Ethnic and Migration Studies, 44(15), 2506-2523.

Bowler, S., \& Hanneman, R. (2006). Just how pluralist is direct democracy? The structure of interest group participation in ballot proposition elections. Political Research Quarterly, 59(4), 557-568.

Bull, M. J. (2016). Renzi removed: The 2016 Italian constitutional referendum and its outcome. Italian Politics, 32(1), 131-153.

Clarke, H. D., Goodwin, M., \& Whiteley, P. (2017). Brexit: Why Britain voted to leave the European Union. Cambridge: Cambridge University Press.

Jasper, J. M. (2006). Getting your way: Strategic dilemmas in the real world. Chicago, IL: The University of Chicago Press.

Kriesi, H. (2005). Direct democratic choice: The Swiss experience. Lanham, MD: Lexington Books.

Kriesi, H. (2006). Role of the political elite in Swiss directdemocratic votes. Party Politics, 12(5), 599-622.

Mahoney, C. (2007). Networking vs. allying: The deci- sion of interest groups to join coalitions in the U.S. and the EU. Journal of European Public Policy, 14(2), 366-383.

Manweller, M. (2005). Coalition building in direct democracy campaigns. American Politics Research, 33(2), 246-282.

McCarthy, J. D., \& Zald, M. N. (1977). Resource mobilization and social movements: A partial theory. American Sociological Review, 82(6), 1212-1241.

Müller, W., \& Strøm, K. (2000). Coalition governments in Western Europe. New York, NY: Oxford University Press.

Pasquino, G., \& Valbruzzi, M. (2017). Italy says no: The 2016 constitutional referendum and its consequences. Journal of Modern Italian Studies, 22(2), 145-162.

Paterson, L. (2015). Utopian pragmatism: Scotland's choice. Scottish Affairs, 24(1), 22-46.

Riker, W. H. (1962). The theory of political coalitions. New Haven, CT: Yale University Press.

Steiner, N. (2000). Arguing about asylum: The complexity of refugee debates in Europe. New York, NY: St. Martin's Press.

van Dyke, N., \& McCammon, H. J. (2010). Strategic alliances: Coalition building and social movements. Minneapolis, MN: University of Minnesota Press.

Wasserman, S., \& Faust, K. (1999). Social network analysis: Methods and application. Cambridge: Cambridge University Press.

\section{About the Author}

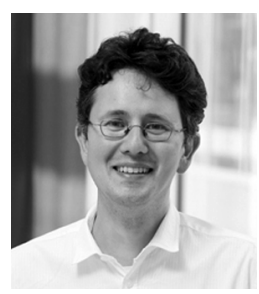

Laurent Bernhard (PhD, University of Zurich) is a Senior Researcher at the Swiss Centre of Expertise Research in the Social Sciences (FORS), which is hosted by the University of Lausanne. He is currently involved in the Swiss Election Study (Selects) as well as in the VOTO surveys. His main research interests include populism, direct democracy, political communication, and asylum policies. 


\section{Appendix}

Table A.1. Actor composition of the opponents of the tightening reform by ICC.

\begin{tabular}{|c|c|c|c|}
\hline & Actor type & Standardized power & Left-right (0-10) \\
\hline \multicolumn{4}{|l|}{ Left and allies } \\
\hline Committee Twofold No & Committee & 0.36 & 3 \\
\hline Social Democrats & Party & 0.23 & 2 \\
\hline Cultural workers against the asylum law & Committee & 0.21 & 2 \\
\hline Stop exclusion & Citizen group & 0.17 & 2 \\
\hline Greens & Party & 0.13 & 1 \\
\hline Solidarity without borders & Citizen group & 0.08 & 1 \\
\hline Forum for the integration of migrants & Citizen group & 0.06 & 3 \\
\hline Sans papiers collective & Citizen group & 0.06 & 2 \\
\hline Unia & Economic association & 0.06 & 2 \\
\hline Swiss Federation of Trade Unions & Economic association & 0.05 & 2 \\
\hline SolidaritéS & Party & 0.04 & 0 \\
\hline Evangelical People's Party & Party & 0.04 & 5 \\
\hline Christian Democrats of the Canton of Geneva & Party & 0.04 & 5 \\
\hline Free Democrats of the Canton of Geneva & Party & 0.04 & 6 \\
\hline AGORA & Citizen group & 0.03 & 3 \\
\hline Comedia & Economic association & 0.03 & 1 \\
\hline Communists & Party & 0.03 & 1 \\
\hline Young Socialists & Party & 0.03 & 1 \\
\hline Christian Democrats of the Canton of Vaud & Party & 0.02 & 5 \\
\hline Travail Suisse & Economic association & 0.01 & 3 \\
\hline \multirow[t]{2}{*}{ Politakt } & Citizen group & 0.00 & 2 \\
\hline & & & 2.48 \\
\hline \multicolumn{4}{|l|}{ Moderates } \\
\hline Right-wing committee against the asylum law & Committee & 0.34 & 5 \\
\hline Swiss Aid for Refugees & Citizen group & 0.33 & 3 \\
\hline Coalition for a humanitarian Switzerland & Committee & 0.31 & 5 \\
\hline Conference of Swiss Bishops & Citizen group & 0.18 & 5 \\
\hline Amnesty international & Citizen group & 0.13 & 5 \\
\hline Charity of the Protestant Churches of Switzerland & Citizen group & 0.13 & 4 \\
\hline Federation of Swiss Protestant Churches & Citizen group & 0.11 & 5 \\
\hline Charity of Swiss Jews & Citizen group & 0.04 & 5 \\
\hline Christians and Jews for the freedom to Aid & Citizen group & 0.04 & 2 \\
\hline Protestant Church of the Canton of Zurich & Citizen group & 0.02 & 4 \\
\hline
\end{tabular}

Note: Within the two ICC, the actors are listed according to their standardized power, which is based on a reputational measure. 
Table A.2. Actor composition of the supporters of the tightening reform by ICC.

\begin{tabular}{|c|c|c|c|}
\hline & Actor type & Standardized power & Left-right (0-10) \\
\hline \multicolumn{4}{|l|}{ Moderate right } \\
\hline Federal Department of Justice and Police & State actor & 0.41 & 6 \\
\hline Federal Office for Migration & State actor & 0.32 & 5 \\
\hline Christian Democrats & Party & 0.13 & 5 \\
\hline Free Democrats & Party & 0.08 & 7 \\
\hline Liberal Party & Party & 0.06 & 6 \\
\hline Small Business Association & Economic association & 0.01 & 8 \\
\hline \multirow[t]{2}{*}{ Swiss Employers' Federation } & Economic association & 0.00 & 8 \\
\hline & & & 6.43 \\
\hline \multicolumn{4}{|l|}{ Radical right } \\
\hline Swiss People's Party & Party & 0.55 & 8 \\
\hline Campaign for an independent and neutral Switzerland & Citizen group & 0.11 & 10 \\
\hline Evangelical Democratic Union & Party & 0.01 & 8 \\
\hline Young4fun.ch & Citizen group & 0.01 & 7 \\
\hline
\end{tabular}

Note: Within the two ICC, the actors are listed according to their standardized power, which is based on a reputational measure.

Table A.3. Actor composition of the opponents of the streamlining reform by ICC.

\begin{tabular}{|c|c|c|c|}
\hline & Actor type & Standardized power & Left-right (0-10) \\
\hline \multicolumn{4}{|l|}{ Radical left } \\
\hline Appeal for the protection of the right to asylum & Committee & 0.13 & 2 \\
\hline SolidaritéS & Party & 0.05 & 1 \\
\hline Stop exclusion & Citizen group & 0.01 & 1 \\
\hline \multirow[t]{2}{*}{ BastA! } & Party & 0.01 & 0 \\
\hline & & & 1.00 \\
\hline \multicolumn{4}{|l|}{ Radical right } \\
\hline Swiss People's Party & Party & 0.65 & 8 \\
\hline Homeowners Association Switzerland & Economic association & 0.17 & 7 \\
\hline Swiss Democrats & Party & 0.02 & 6 \\
\hline \multirow[t]{2}{*}{ Security for all! } & Citizen group & 0.02 & 8 \\
\hline & & & 7.25 \\
\hline
\end{tabular}

Note: Within the two ICC, the actors are listed according to their standardized power, which is based on a reputational measure. 
Table A.4. Actor composition of the supporters of the streamlining reform by ICC.

\begin{tabular}{|c|c|c|c|}
\hline & Actor type & Standardized power & Left-right (0-10) \\
\hline \multicolumn{4}{|l|}{ Left and allies } \\
\hline Operation Libero & Citizen group & 0.28 & 5 \\
\hline Amnesty international & Citizen group & 0.19 & 5 \\
\hline Charity of the Protestant Churches of Switzerland & Citizen group & 0.17 & 3 \\
\hline Greens & Party & 0.12 & 2 \\
\hline Solidarity without borders & Citizen group & 0.08 & 2 \\
\hline Caritas & Citizen group & 0.04 & 4 \\
\hline Young Socialists & Party & 0.03 & 1 \\
\hline Federation of Swiss Protestant Churches & Citizen group & 0.02 & 4 \\
\hline Swiss Aid for Refugees & Citizen group & 0.01 & 3 \\
\hline Swiss Workers' Aid Organization & Citizen group & 0.01 & 2 \\
\hline Unia & Economic association & 0.01 & 3 \\
\hline \multirow[t]{2}{*}{ Conference of Swiss Bishops } & Citizen group & 0.00 & 5 \\
\hline & & & 3.25 \\
\hline \multicolumn{4}{|l|}{ Moderates } \\
\hline Federal Department of Justice and Police & State actor & 0.58 & 5 \\
\hline State Secretariat for Migration & State actor & 0.41 & 5 \\
\hline Social Democrats & Party & 0.27 & 2 \\
\hline Cantonal Directors of Justice and Police & State actor & 0.20 & 7 \\
\hline Christian Democrats & Party & 0.22 & 6 \\
\hline Free Democrats & Party & 0.19 & 7 \\
\hline Cantonal Social Directors & State actor & 0.09 & 3 \\
\hline Conservative Democrats & Party & 0.04 & 6 \\
\hline Green Liberals & Party & 0.03 & 5 \\
\hline Swiss Associations of Cities & State actor & 0.03 & 5 \\
\hline \multirow[t]{2}{*}{ Evangelical People's Party } & Party & 0.01 & 4 \\
\hline & & & 5.00 \\
\hline
\end{tabular}

Note: Within the two ICC, the actors are listed according to their standardized power, which is based on a reputational measure. 